Journal of Advanced Research in Fluid Mechanics and Thermal Sciences

Journal homepage: www.akademiabaru.com/arfmts.html ISSN: $2289-7879$

\title{
The Significant Effect of Liquid Viscosity on Two-Phase Flow Pressure Gradient in Mini Channel with Slope of $15^{\circ}$ against Horizontal
}

\author{
Sukamta ${ }^{1, *}$, Sudarja $^{1}$ \\ 1 Universitas Muhammadiyah Yogyakarta, Yogyakarta, 55183, Indonesia
}

\section{\begin{tabular}{l} 
ARTICLE INFO ABSTRACT \\
\hline
\end{tabular}}

\section{Article history:}

Received 18 January 2020

Received in revised form 25 February 2020

Accepted 2 March 2020

Available online 26 April 2020
Keywords:

concentration; gas-water; mini channel; mixture; superficial; velocity

\begin{abstract}
Two-phase flow is found in daily life as well as in the field of industry, which consists of three phases, namely liquid-solid, gas-liquid, and gas-solid. The fundamental characteristics of two-phase flow include flow pattern and flow pattern maps, void fraction, and pressure gradient. Some problems related to the pressure gradient comprise of the superficial velocity and viscosity of fluid mixture flow. This research discussed the significant effect of liquid viscosity in two-phase flow pressure gradient to find out the influence of liquid velocity, and also both superficial gas velocity $\left(J_{G}\right)$ and liquid superficial velocity $\left(\mathrm{J}_{\mathrm{L}}\right)$ on the pressure gradient. This research used a capillary pipe with a diameter of $1.6 \mathrm{~mm}$. The fluid used was a gas-water mixture and glycerin with a concentration of $40 \%, 50 \%, 60 \%$, and $70 \%$. The pressure drop was measured using a pressure transducer and recorded by data acquisition. The result showed that the value of the two-phase flow pressure gradient was affected significantly by the number of liquid viscosity. The higher liquid viscosity leads to an increase in the twophase flow pressure gradient. The pressure gradient was also effected either by liquid or gas superficial velocity, namely, the higher the superficial velocity of either by liquid or gas, the higher the pressure gradient.
\end{abstract}

Copyright $\odot 2020$ PENERBIT AKADEMIA BARU - All rights reserved

\section{Introduction}

Two-phase/component flows in the mini channel or capillary pipe is commonly implemented in daily life and also in the industrial sector. In daily life, two-component or multicomponent flow in a capillary pipe is applied in the blood flow system in the human body. In the industrial sector, twophase flow in the capillary pipe is applied in the mini heat exchanger, mini evaporator, mini condenser, Micro Electro Mechanical System (MEMS), etc. The basic characteristics of two-phase flow in the capillary pipe are flow pattern or flow regime, flow pattern map, void fraction, pressure gradient or pressure drop. Many experiments have been conducted to study the two-phase flow. The

\footnotetext{
* Corresponding author.

E-mail address: sukamta@umy.ac.id (Sukamta)
}

https://doi.org/10.37934/arfmts.70.2.116123 
studies that had been done by the researchers were generally using a pipe with normal and large size.

Fukano and Kariyaki [1] studied the characteristic of gas-water two-phase flow in a capillary pipe with a diameter of $1 \mathrm{~mm}, 2.4 \mathrm{~mm}$, and $4.9 \mathrm{~mm}$. Ali et al., [2] showed the data of a study on pressure drop in the form of a friction factor of single-phase or two-phase. Triplett et al., [3] conducted an experiment on void fraction and pressure drop that were caused by the friction of two-phase flow in a pipe with a diameter of $1.1 \mathrm{~mm}$ and $1.45 \mathrm{~mm}$. Ju Lee, Han Yong Lee, Sang Lee and Lee [4] suggested a new correlation of pressure drop through a rectangular channel horizontal position with slit drop. Kawahara [5] conducted an experimental investigation on the characteristic of two-phase flow in a pipe with a diameter of 100 micrometers. Wongwises and Pipathatta [6] carried out an experiment on the flow pattern, pressure drop, and void fraction in the two-phase flow in a horizontal pipe, and mini slit annular channel slope with an outer diameter of $12.5 \mathrm{~mm}$ and an inner diameter of $8 \mathrm{~mm}$. Saisorn and Wongwises [7] investigated the characteristics of two-phase flow, void fraction, and pressure drop in a micro circular channel with a diameter of $0.53 \mathrm{~mm}$ in a horizontal position. Barreto et al., [8] studied the analysis on pressure drop and void fraction of two-phase flow in a microchannel. Abubakar et al., [9] stated that the pressure gradient would increase as well as the increase of mixture viscosity. Gunawan et al., [10] experimented with pressure difference in an acrylic pipe with an inner diameter of $26 \mathrm{~mm}$. Meanwhile, an experimental study has also been carried out in the reduction of the friction pressure of two-phase flow on a microchannel with a diameter of $500 \mu \mathrm{m}$ and a length of $0.5 \mathrm{~m}$ with a homogeneous and separate model. Several correlations exist of the two-phase flow viscosity and density used to predict the decrease in friction pressure. A comparison of predicted friction pressure drop shows that the correlation of Hibiki, Xuejiao, and Pamitran from separated models [11]. Sudarja et al., [12] studied the pressure gradient of the two-phase flow of gas-water and glycerin $20 \%$ in a glass pipe with an inner diameter of $1.6 \mathrm{~mm}$. Previous research has presented an analytical model for the calculation of two-phase pressure reduction using four refrigerants and test parameters namely vapor quality and mass flux. The pressure-drop model was examined with four coolants: R134a, R507A, R600a, and R1234xyh. The results show that there is a match between the two-phase pressure drop behavior for parameters that are fully variable compared to previous work so that this model can contribute to the design of heat exchangers and/or condensation tubes for other coolers [13]. To the best of the author's knowledge, the information on the pressure gradient in the capillary pipe with the variation of viscosity is still limited. Therefore, this study aims to obtain the information on the effect of superficial velocity and viscosity of the mixture of water-glycerin $(40 \%, 50 \%, 60 \%$, and $70 \%)$ against the pressure gradient in a horizontal capillary pipe with the slope of $15^{\circ}$.

\section{Research Method}

The used tool scheme in this study can be shown in Figure 1. This scheme consisted of some components, i.e., water tanks, water pumps, air compressors, pressure vessels, test sections, water traps, mixers, and connectors. The supporting tools used in this study were amplifiers, optical correction boxes, cameras, computers, video processing systems, and acquisition systems. The measurement tools used in this study were water flow meter, airflow meter, temperature indicator, thermocouple, pressure indicator, and pressure transducer. For streaming video shooting, a highspeed camera Nikon type J4 with a speed of $1200 \mathrm{fps}$ and a resolution of $640 \times 480$ pixels was used. The data acquisition from "National Instrument" was used to convert data from analog to digital; then it could be recorded, stored, processed, and analyzed on a computer. The condition of this study 
was adiabatic. The experiment was done in the superficial gas velocity $\left(\mathrm{J}_{\mathrm{G}}\right)$ with an interval of 0.025 $-66.3 \mathrm{~m} / \mathrm{s}$, and the superficial liquid velocity $\left(\mathrm{J}_{\mathrm{L}}\right)$ with the range of $0.033-4.935 \mathrm{~m} / \mathrm{s}$.

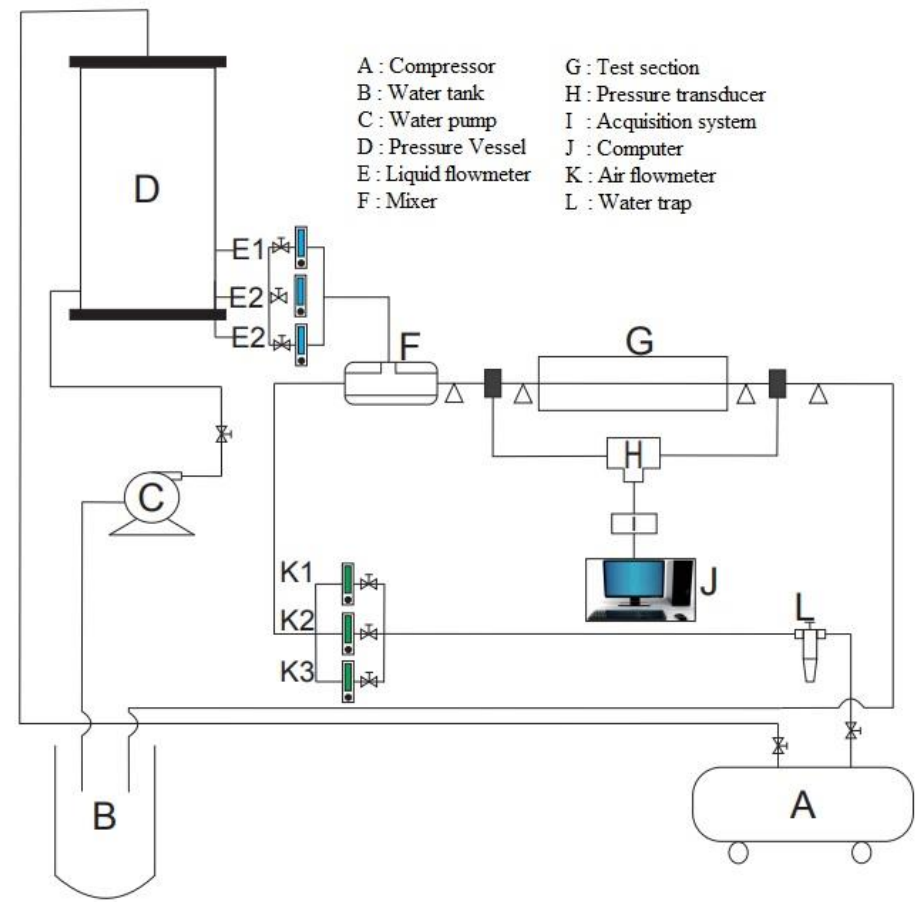

Fig. 1. Scheme of Research Installation

\section{Result and Discussion}

This study discussed the pressure drop per unit length (pressure gradient) two-phase flow in a capillary pipe with a diameter of $1.6 \mathrm{~mm}$ and the variation of viscosity and $\mathrm{J}_{\mathrm{G}}-\mathrm{J}_{\mathrm{L}}$. The variety of viscosity was done by providing the mixture with the glycerin percentage of $40 \%(G L 40), 50 \%(G L 50)$, $60 \%(G L 60)$, and $70 \%(G L 70)$. The data of the pressure gradient were taken by using the sensor of a pressure transducer (PT). After doing the research, it was obtained some data according to the variation of superficial gas velocity $\left(\mathrm{J}_{G}\right)$ and superficial liquid velocity $\left(\mathrm{J}_{\mathrm{L}}\right)$. In addition to superficial velocity variations, variations in viscosity were also carried out in this study.

This study implemented the variation of superficial gas velocity $\left(\mathrm{J}_{\mathrm{G}}\right)$ and superficial liquid velocity $\left(J_{L}\right)$. This variation was done to obtain the effect that could occur because of the increase and decrease of superficial velocity on the pressure gradient. This study was done by using the variation of superficial velocity both for gas or liquid. This thing was done to show the effect of the change of the superficial velocity on the value of the pressure gradient in the capillary pipe with a diameter of $1.6 \mathrm{~mm}$. Figure 2-3 shows the effect of superficial gas velocity $\left(\mathrm{J}_{\mathrm{G}}\right)$ in the variation of superficial liquid velocity $\left(\mathrm{J}_{\mathrm{L}}\right)$. The superficial velocity was measured by using the air and liquid rotameter with three range $J_{L}(0.149 ; 0.879$ and $2.297[\mathrm{~m} / \mathrm{s}])$ and also by varying the $J_{G}(0-66.3[\mathrm{~m} / \mathrm{s}])$ in every $J_{L}$. Meanwhile, Figure 2-3 also shows the effect of $\mathrm{J}_{\mathrm{L}}$ in the variation of $\mathrm{J}_{\mathrm{G}}$. Based on these data, it can be known that the pressure gradient $(\Delta \mathrm{P} / \Delta \mathrm{Z})$ is the function of $\mathrm{J}_{\mathrm{G}}$ dan $\mathrm{J}_{\mathrm{L}}$. From these studies mentioned above, it can be seen that if the superficial gas velocity $(\mathrm{Jg})$ increases, then the value of the pressure gradient will increase, as well as the superficial liquid velocity ( $\left.\mathrm{L}_{\mathrm{L}}\right)$. Previously, Sudarja et al., [14] had also conducted an experimental study on the adiabatic flow pattern of two-phase gas-liquid flow in mini-channel with inner diameters of $1.6 \mathrm{~mm}$ and the range of gas and liquid velocity were respectively $0.025-66.3 \mathrm{~m} / \mathrm{s}$ and $0.033-4.935 \mathrm{~m} / \mathrm{s}$. Working fluids are used air and water-glycerine 
solutions with various concentrations ranging from $20-60 \%$. The research obtained data of bubbly, plug, slug-annular, annular, and churn flow patterns. It was also found that changes in liquid viscosity affect the shape of the flow pattern that occurs.

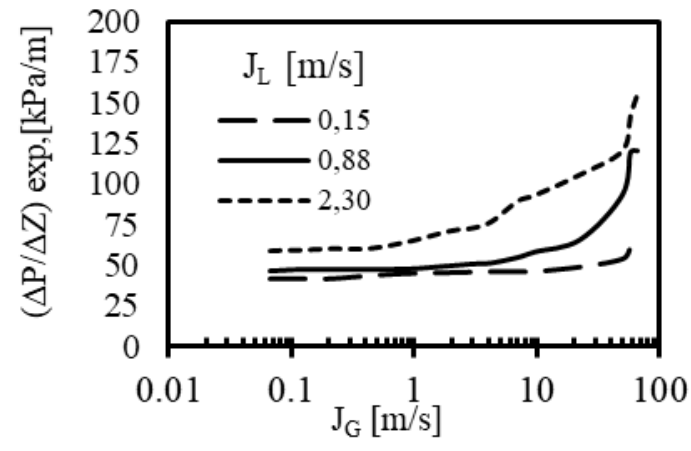

(a)

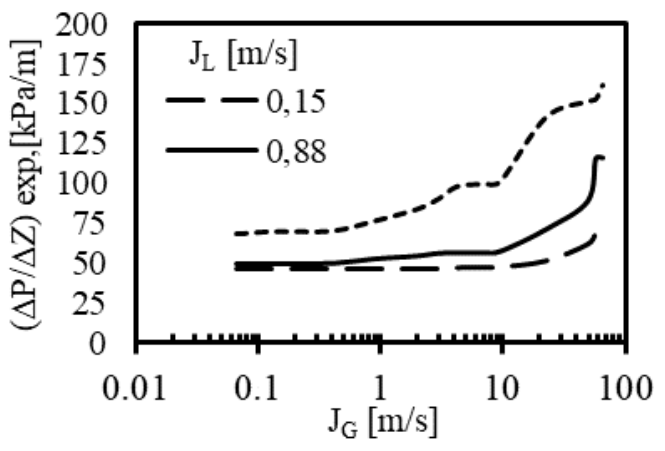

(b)

Fig. 2. Effect of JG on pressure gradients with variations JL on (a).GL40, (b). GL50

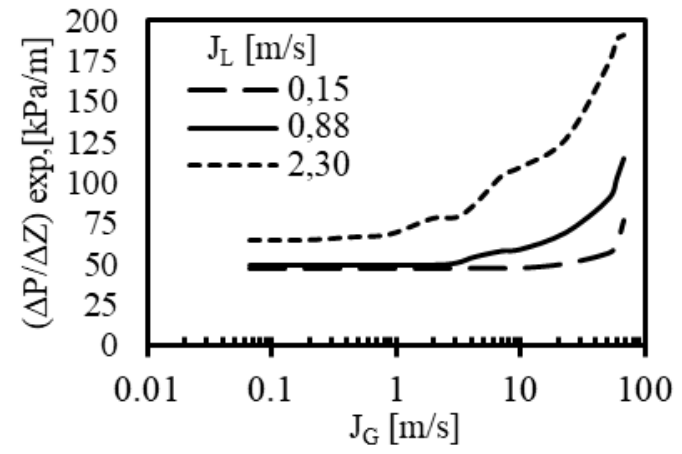

(a)

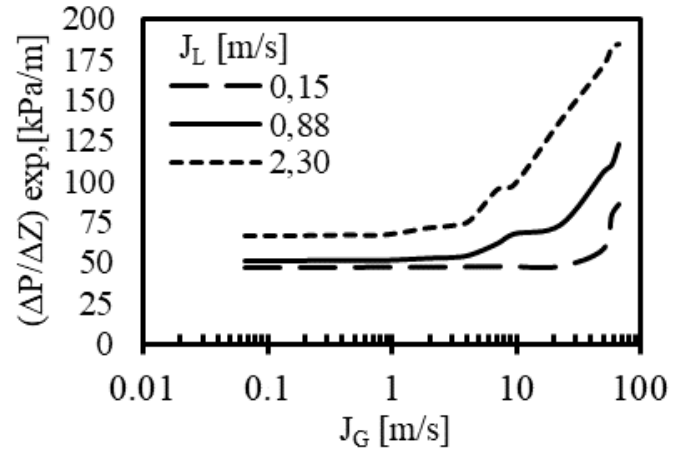

(b)

Fig. 3. Effect of JG on pressure gradients with variations JL on (a). GL60, (b). GL70

Meanwhile, Figure 4 shows that the viscosity of glycerin significantly affects the value of the pressure gradient. From the Figure, it can be seen that if the viscosity increases, then the value of the pressure gradient will increase as well. Research on the characteristics of two-phase oil-gas flow with high viscosity has been carried out to show some significant differences with the characteristics of low viscosity liquids. This experiment uses a $26 \mathrm{~mm}$ ID and 5.5 test tubes. $\mathrm{m}$ long horizontal pipes, with a variety of liquid viscosity from 1000 . cP to 7500 . cP. Superficial oil and gas velocity varies from $0.06 . \mathrm{m} / \mathrm{s}$ to $0.5 \mathrm{~m} / \mathrm{s}$ and starting at $0.3 \mathrm{~m} / \mathrm{s}$ to $12.0 \mathrm{~m} / \mathrm{s}$ respectively. The results of the study were compared with existing models and showed significant differences between liquids and gases with low and high viscosity[15]. In previous studies, there were also studies that focused on the effect of viscosity of fluids on the effect of entrances on vertical pipes with a diameter of $127 \mathrm{~mm}$, gas superficial velocity varying between $0.01-5.40 \mathrm{~m} / \mathrm{s}$, superficial liquid velocity between 0.07-0.86 $\mathrm{m}$ / $\mathrm{s}$, the viscosity is between $4.0 \mathrm{cP}$ up to $104.6 \mathrm{cP}$. Vacuum fraction was measured using Electrical Capacitance Tomography and Wire Mesh Sensors, while differential pressure measurements using sensors [16]. On the other hand, experimental observations of fluid flow in the microchannel have been made for various variables. Experimental findings indicate changes in viscosity as a cause of deviation from conventional flow theory for macro channels. Based on an analysis of numerical friction factors, the entrance effect must be taken into account for any microfluidic system [17]. 


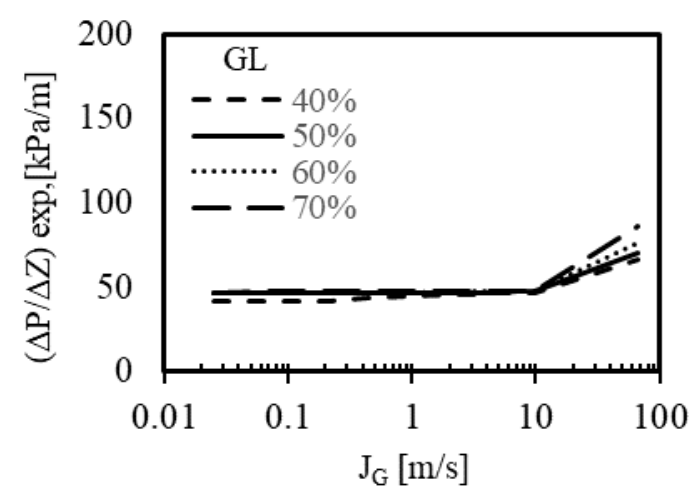

(a)

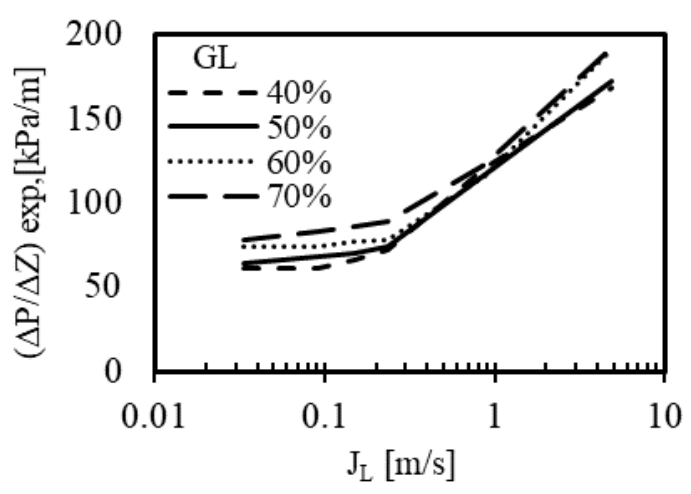

(b)

Fig. 4. The effect of fluid viscosity on pressure gradients on (a). JL $0.149 \mathrm{~m} / \mathrm{s}$ and JG varies, (b) JG $66.3 \mathrm{~m} / \mathrm{s}$ and $\mathrm{JL}$ varies

The value of the pressure gradient $(\Delta \mathrm{P} / \Delta \mathrm{Z})$ can also be seen in the time-series data. Figure 5 shows a pressure gradient against time at $J_{G}=0.066[\mathrm{~m} / \mathrm{s}]$ and $J_{L}=0.7[\mathrm{~m} / \mathrm{s}]$ for 0.5 seconds. The figure shows the mean pressure gradient is at 43.62 (GL40) and $48.78 \mathrm{kPa} / \mathrm{m}(\mathrm{GL70})$.

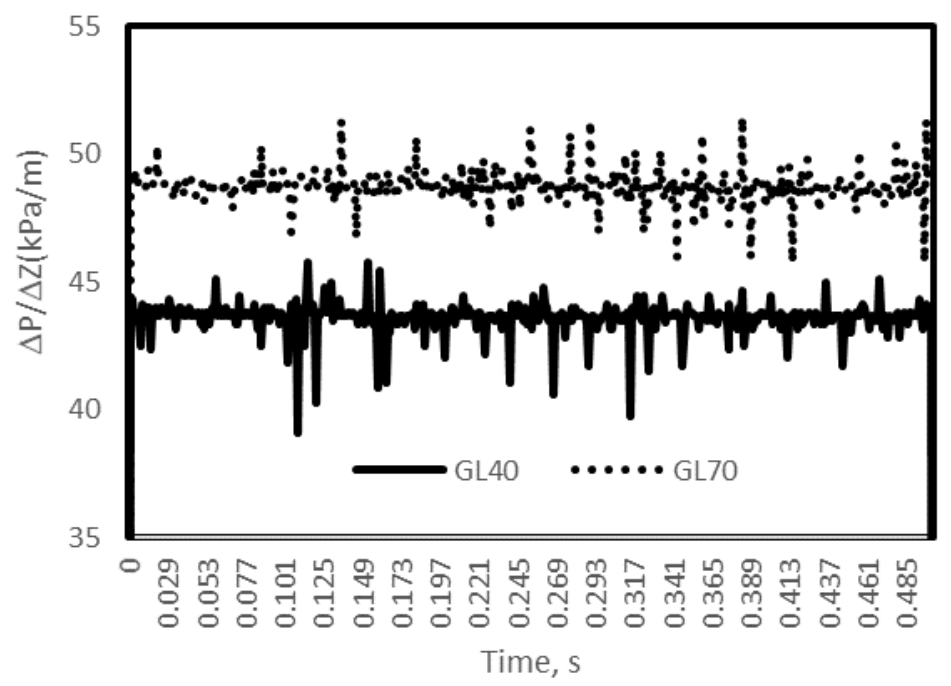

Fig. 5. Time series of pressure gradient at JG $=0.066[\mathrm{~m} / \mathrm{s}]$ and $\mathrm{JL}=0.7[\mathrm{~m} / \mathrm{s}] \mathrm{GL} 40$ and $\mathrm{GL70}$

Figure 6 shows a graph of the pressure gradient probability density function at GL40 and GL70. From the two figures can be drawn physical meaning that the increase in viscosity, the pressure gradient will also increase. Recently, an experimental study of two-phase gas-liquid flow pressure gradients in a mini-channel $\left(d_{\text {in }} 1.6 \mathrm{~mm}\right.$ ), superficial velocity of gases and liquids were in the range of $0.025-66,300 \mathrm{~m} / \mathrm{s}$ and $0.033-4,935 \mathrm{~m} / \mathrm{s}$, respectively has concluded that the velocity of superficial gases and liquids is proportional to the pressure gradient[18]. Previous studies have also studied the flow of air-water in sharp $90^{\circ}$ elbows for Reynolds numbers of 5600-12800. The results showed that the length of the upstream and downstream elbow disturbance and pressure drop were significantly affected by flow patterns[19]. The effects of vapor quality and internal diameter on a two-phase pressure drop were presented in previous studies with test equipment made of tubular stainless steel with an internal diameter of $1.70 \mathrm{~mm}$ and $1.224 \mathrm{~mm}$ and a length of $245 \mathrm{~mm}$. Some general twophase pressure reduction correlations suggested for macro and micro-scale channels are examined by comparing them with experimental data. None of the correlations examined agreed with this 
research test data. A new correlation is proposed which is able to predict experimental data with MAD $16 \%$ and $86 \%$ data in the AE30\% range[20]. The correlation effect of void fractions on the pressure gradient of two-phase water-air flow in vertical rectangular channels was investigated with superficial gas and liquid velocity ranging from 0.58 to $32 \mathrm{~m} / \mathrm{s}$ and from 0.16 to $3.8 \mathrm{~m} / \mathrm{s}$. The results showed that the void fraction had a large influence on the pressure gradient on the slug flow pattern and churn flow but did not affect the bubble and annular flow. Furthermore, void fraction correlation has a smaller effect on the pressure gradient separation due to decreased channel size[21].

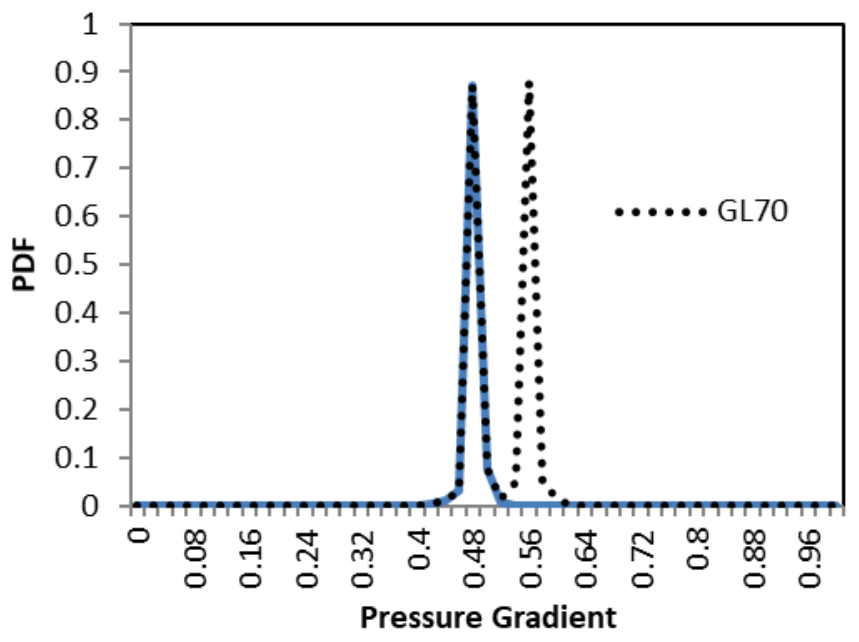

Fig. 6. Probability Density Function of pressure gradient at JG $=0.066[\mathrm{~m} / \mathrm{s}]$ and $\mathrm{JL}=0.7[\mathrm{~m} / \mathrm{s}](\mathrm{a}) \mathrm{GL} 40$, (b) GL70

\section{Conclusion}

Based on the research result that has been done in two-phase flow, it can be concluded that the superficial gas velocity $(\mathrm{Jg})$ and superficial liquid velocity $\left(\mathrm{J}_{\mathrm{L}}\right)$ significantly affect the value of the pressure gradient. The pressure gradient increases because of the effect of $J_{L}$ with the range of 0.15 ; $0.88 ; 2.30 \mathrm{~m} / \mathrm{s}$ and the variation of $\mathrm{J}_{\mathrm{G}} 0-66.3 \mathrm{~m} / \mathrm{s}$. The pressure gradient also increases because of the impact of $J_{G}$ in the range of $0.07 ; 7.00 ; 22.60 \mathrm{~m} / \mathrm{s}$ and the variation of $J_{L} 0.03-4.94 \mathrm{~m} / \mathrm{s}$. The viscosity of glycerin has a significant effect on the value of the pressure gradient. From the result of the research on the $G L 40 \%, 50 \%, 60 \%$, and $70 \%$ with $J_{G}=0.066[\mathrm{~m} / \mathrm{s}]$ and $J_{L}=0.7[\mathrm{~m} / \mathrm{s}]$, it can be seen that the increase of pressure gradient value leads to the increase of glycerin viscosity.

\section{Acknowledgment}

Thanks to the Ministry of Research, Technology and the Higher Education Republic of Indonesia for the Research Funds on the scheme of PDUPT with contract no. 111/SP2H/LT/DRPM/2019. I would like to express my gratitude for Rizal Fakhri supported and measured data.

\section{References}

[1] Fukano, Tohru, and Akira Kariyasaki. "Characteristics of gas-liquid two-phase flow in a capillary tube." Nuclear Engineering and Design 141, no. 1-2 (1993): 59-68. https://doi.org/10.1016/0029-5493(93)90092-N

[2] Ali, Muhammad I., Michio Sadatomi, and Masahiro Kawaji. "Adiabatic two-phase flow in narrow channels between two flat plates." The Canadian Journal of Chemical Engineering 71, no. 5 (1993): 657-666. https://doi.org/10.1002/cjce.5450710502

[3] English, Nathan J., and Satish G. Kandlikar. "An experimental investigation into the effect of surfactants on air-water 
two-phase flow in minichannels." Heat transfer engineering 27, no. 4 (2006): 99-109.

https://doi.org/10.1080/01457630500523980

[4] Lee, Han Ju, and Sang Yong Lee. "Pressure drop correlations for two-phase flow within horizontal rectangular channels with small heights." International journal of multiphase flow 27, no. 5 (2001): 783-796.

https://doi.org/10.1016/S0301-9322(00)00050-1

[5] Kawahara, A., PM-Y. Chung, and M. Kawaji. "Investigation of two-phase flow pattern, void fraction and pressure drop in a microchannel." International journal of multiphase flow 28, no. 9 (2002): 1411-1435.

https://doi.org/10.1016/S0301-9322(02)00037-X

[6] Wongwises, Somchai, and Manop Pipathattakul. "Flow pattern, pressure drop and void fraction of two-phase gasliquid flow in an inclined narrow annular channel." Experimental Thermal and Fluid Science 30, no. 4 (2006): $345-$ 354.

https://doi.org/10.1016/i.expthermflusci.2005.08.002

[7] Saisorn, Sira, and Somchai Wongwises. "Flow pattern, void fraction and pressure drop of two-phase air-water flow in a horizontal circular micro-channel." Experimental Thermal and Fluid Science 32, no. 3 (2008): 748-760.

https://doi.org/10.1016/i.expthermflusci.2007.09.005

[8] Barreto, E. X., J. L. G. Oliveira, and J. C. Passos. "Frictional pressure drop and void fraction analysis in air-water twophase flow in a microchannel." International Journal of Multiphase Flow 72 (2015): 1-10.

https://doi.org/10.1016/j.ijmultiphaseflow.2015.01.008

[9] Abubakar, A., Y. Al-Wahaibi, T. Al-Wahaibi, A. Al-Hashmi, A. Al-Ajmi, and M. Eshrati. "Effect of low interfacial tension on flow patterns, pressure gradients and holdups of medium-viscosity oil/water flow in horizontal pipe." Experimental Thermal and Fluid Science 68 (2015): 58-67.

https://doi.org/10.1016/i.expthermflusci.2015.02.017

[10] D. Gunawan, A. Z. Hudaya, F. Teknik, and U. G. Mada. "Tegangan Geser Antarmuka Pada Aliran Stratified Air." Engineering 10, no. 1 (2015): 32-40.

[11] Novianto, S., Agus Sunjarianto Pamitran, R. Koestoer, and K. Saito. "Two-phase frictional pressure drop of propane with prediction methods of viscosity and density in $500 \mu \mathrm{m}$ diameter tube." In IOP Conference Series: Materials Science and Engineering, vol. 316, no. 1, p. 012058. IOP Publishing, 2018. https://doi.org/10.1088/1757-899X/316/1/012058

[12] Sudarja, F. Jayadi, Indarto, and Deendarlianto. "Karakteristik Gradien Tekanan Pada Aliran Dua-Fase UdaraCampuran Air dan 20 \% Gliserin Dalam Pipa Horizontal Berukuran Mini (Characteristics of Pressure Gradients in Two-Phase Air-Mixed Water Flow and 20\% Glycerin in Mini-Size Horizontal Pipes)." Proceeding Natl. Symp. Thermofluids VIII, 2016.

[13] Morad, Akeel Mohammed Ali. "A Two-Phase Pressure Drop Model for Homogenous Separated Flow for Circular Tube Condenser, Examined with Four Modern Refrigerants." Journal of Advanced Research in Fluid Mechanics and Thermal Sciences 52, no. 2 (2018): 274-287.

[14] Sudarja, Farid Jayadi, Indarto, Deendarlianto, and Adhika Widyaparaga. "The effect of liquid viscosity on the gasliquid two-phase flow pattern in horizontal mini-channel." In AIP Conference Proceedings, vol. 2001, no. 1, p. 030010. AIP Publishing LLC, 2018.

https://doi.org/10.1063/1.5049982

[15] Zhao, Y., H. Yeung, E. E. Zorgani, A. E. Archibong, and L. Lao. "High viscosity effects on characteristics of oil and gas two-phase flow in horizontal pipes." Chemical Engineering Science 95 (2013): 343-352. https://doi.org/10.1016/i.ces.2013.03.004

[16] Ibrahim, Abubakr, Buddhika Hewakandamby, Zhilin Yang, and Barry Azzopardi. "Effect of Liquid Viscosity on TwoPhase Flow Development in a Vertical Large Diameter Pipe." In ASME 2018 5th Joint US-European Fluids Engineering Division Summer Meeting. American Society of Mechanical Engineers Digital Collection, 2018.

https://doi.org/10.1115/FEDSM2018-83466

[17] Koo, Junemo, and Clement Kleinstreuer. "Liquid flow in microchannels: experimental observations and computational analyses of microfluidics effects." Journal of Micromechanics and Microengineering 13, no. 5 (2003): 568-579.

https://doi.org/10.1088/0960-1317/13/5/307

[18] Sudarja, A. Haq, Deendarlianto, Indarto, and A. Widyaparaga. "Experimental study on the flow pattern and pressure gradient of air-water two-phase flow in a horizontal circular mini-channel." Journal of Hydrodynamics 31, no. 1 (2019): 102-116. https://doi.org/10.1007/s42241-018-0126-2

[19] Al-Tameemi, Wameedh TM, and Pierre Ricco. "Pattern-based pressure drop of air-water flow across a $90^{\circ}$ sharp miter elbow." Multiphase Flow: Theory and Applications 6, no. 1 (2018): 198-207. https://doi.org/10.2495/CMEM-V6-N1-198-207 
[20] Maqbool, Muhammad Hamayun, Björn Palm, and Rahmatollah Khodabandeh. "Flow boiling of ammonia in vertical small diameter tubes: Two phase frictional pressure drop results and assessment of prediction methods." International journal of thermal sciences 54 (2012): 1-12.

https://doi.org/10.1016/j.ijthermalsci.2011.11.018

[21] Xing, Dianchuan, Changqi Yan, Xinguang Ma, and Licheng Sun. "Effects of void fraction correlations on pressure gradient separation of air-water two-phase flow in vertical mini rectangular ducts." Progress in Nuclear Energy 70 (2014): 84-90.

https://doi.org/10.1016/i.pnucene.2013.08.003 